Publicado pela primeira vez em 1973, no número 5 da revista Cause commune, "Approches de quoi" faz parte de um dossiê dedicado às noçōes de "infra-ordinário" e "infra-cotidiano", que reúne também artigos de Jean Duvignaud e Paul Virilio. Na forma de um pequeno ensaio, esse texto de Georges Perec pode ser considerado uma peça capital do quebra-cabeça que irá formar sua produção. Nele, o escritor desenvolve toda a potência de suas reflexões sobre o que chamará de "ruído de fundo", espécie de "resto" que compõe o dia a dia da vida humana, mas ao qual não prestamos atenção. Elaborando uma crítica radical ao espetacular, Perec nos oferece em poucas linhas as bases do pensamento ao mesmo tempo ético e estético que aparece de forma clara em produções como Tentative d'épuisement d'un lieu parisien e Espèces d'espaces. Porém, talvez seja no âmbito da própria ficção que o autor tenha deixado as marcas mais interessantes deste cruzamento entre ética e estética, elaborando uma poética que, influenciada pela sua participação junto ao grupo OuLiPo, dará forma ao romance La Vie mode d'emploi. ${ }^{1}$

Rodrigo Silva lelpo

\footnotetext{
${ }^{1}$ Em 2009, a Companhia das Letras reeditou a tradução de Ivo Barroso para o romance, sob o título A vida, modo de usar.
} 


\section{APROXIMAÇÕES DO QUÊ?}

Georges Perec

O que nos fala, ao que me parece, é sempre o acontecimento, o insólito, o extra-ordinário: cinco colunas na primeira página, largas manchetes. Os trens só começam a existir quando descarrilam, e quanto maior é o número de viajantes mortos, mais eles existem; os aviōes só ganham existência quando se perdem; os carros têm por único destino chocar-se contra os plátanos: cinquenta e dois finais de semana por ano, cinquenta e duas estatísticas: muitos mortos, e tanto melhor para a informação se os números não param de crescer! É preciso que haja por detrás do acontecimento um escândalo, uma fissura, um perigo, como se a vida só devesse se revelar através do espetacular, como se o eloquente, o significativo fosse sempre anormal: cataclismos naturais ou reviravoltas históricas, conflitos sociais, escândalos políticos...

$\mathrm{Na}$ nossa precipitação em medir o histórico, o significativo, o revelador, não deixemos de lado o essencial: o verdadeiramente intolerável, o verdadeiramente inadmissível: o escândalo não é a explosão, é o trabalho nas minas. As "perturbações sociais" não são preocupantes em períodos de greve, elas são intoleráveis vinte e quatro horas por dia, trezentos e sessenta e cinco dias por ano.

Os maremotos, as erupçóes vulcânicas, as torres que desabam, os incêndios das florestas, os túneis que desmoronam, Publicis ${ }^{1}$ que queima e Aranda ${ }^{2}$ que fala! Horrível! Terrível! Monstruoso! Escandaloso! Mas onde está o escândalo? O verdadeiro escândalo? Os jornais não nos dizem outra coisa a não ser: fiquem tranquilos, vocês bem sabem que a vida existe, com os seus altos e baixos, vocês bem sabem que coisas acontecem.

Os jornais falam de tudo, exceto do corriqueiro. Os jornais são um tédio, não me ensinam nada; o que contam não me diz respeito, não me questiona e tampouco responde às perguntas que faço ou que gostaria de fazer.

\footnotetext{
${ }^{1}$ Em setembro de 1972, o prédio da agência de comunicação Publicis, localizado na avenida Champs Élysées, pegou fogo, levando à destruição completa do imóvel. (N. do T.)

${ }^{2}$ Gabriel Aranda, alto funcionário durante o mandato do presidente francês Georges Pompidou, denunciou à imprensa, no início da década de 1970, fatos comprometedores da classe política do seu país. O episódio ficou conhecido como Scandale Aranda. (N. do T.)
} 
O que acontece realmente, o que vivemos, o resto, todo o resto, onde ele está? $\mathrm{O}$ que acontece a cada dia e que sempre retorna, o banal, o cotidiano, o evidente, o comum, o ordinário, o infraordinário, o ruído de fundo, o habitual, como dar conta disso, como interrogá-lo, como descrevê-lo?

Interrogar o habitual. Mas justamente, estamos acostumados a ele. Nós não o interrogamos, ele não nos interroga, ele parece não causar problemas, nós o vivemos sem pensar nisso, como se ele não veiculasse nem perguntas nem respostas, como se não fosse portador de qualquer informação. Não é nem mais condicionamento, mas anestesia. Dormimos nossa vida em um sono sem sonhos. Mas onde está nossa vida? Onde está nosso corpo? Onde está nosso espaço?

Como falar dessas "coisas comuns", ou melhor, como cercálas, trazê-las para fora, arrancá-las da casca onde estão presas, como dar-lhes um sentido, uma língua: que elas falem enfim do que é, do que somos.

Talvez, trate-se de fundar finalmente nossa própria antropologia: aquela que falará de nós, que irá procurar em nós aquilo que durante tanto tempo pilhamos dos outros. Não mais o exótico, mas o endótico.

Interrogar o que parece tão natural que esquecemos sua origem. Reencontrar alguma coisa do espanto que podia sentir Jules Verne ou seus leitores diante de um aparelho capaz de reproduzir e transportar os sons. Pois esse espanto existiu, assim como tantos outros, e são eles que nos modelaram.

O que é preciso interrogar é o tijolo, o concreto, o copo, nosso comportamento à mesa, nossas ferramentas, a organização de nossas ocupaçôes, nossos ritmos. Interrogar o que parece ter cessado para sempre de nos espantar. É claro que vivemos, que respiramos; nós andamos, abrimos portas, descemos escadas, sentamonos à mesa para comer, deitamos em uma cama para dormir. Como? Quando? Por quê?

Descreva a sua rua. Descreva uma outra. Compare.

Faça o inventário de seu bolso, de sua bolsa. Interrogue-se sobre a procedência, o uso e o devir de cada um dos objetos que você retirar daí. 
Questione suas colheres.

O que há debaixo do seu papel de parede?

Quantos gestos são necessários para discar um número de telefone? Por quê?

Por que não encontramos cigarros nas mercearias?3 Por que não?

Pouco me importa que estas perguntas sejam fragmentadas, apenas indicativas de um método, quando muito de um projeto. $\mathrm{O}$ que me importa é que elas pareçam triviais e fúteis: é precisamente o que as torna do mesmo modo essenciais, senão mais, que tantas outras perguntas através das quais tentamos inutilmente captar nossa verdade.

Tradução de Rodrigo Silva lelpo (Doutorando UFRJ/ Paris 7)

\footnotetext{
${ }^{3} \mathrm{Na}$ França, os cigarros são vendidos nos chamados bureaux de tabac. (N. do T.)
} 